\title{
Antibacterial activity of Cefixime against Salmonella typhi and applicability of Etest
}

Yoshimi Matsumoto*, Akiko Ikemoto, Akiko Wakabayashi, John Pitt, Takashi Hirano, Hitoshi Nishio, Shuichi Tawara

\begin{abstract}
Abstrak
Aktivitas in vitro berbagai antibiotika termasuk sefiksim terhadap 73 isolat klinis Salmonella typhi dari berbagai sumber telah dievaluasi menggunakan metoda dilusi agar konvensional dan Etest. 18 dari 73 galur tersebut resisten terhadap kloramfenikol dan kotrimoksasol (sulfametoksasol-trimetoprim), dan 12 dari 18 galur ini juga resisten terhadap amoksisilin karena memproduksi $\beta$-lakıamase. Sefiksim menunjukkan aktivitas yang baik untuk ke 73 galur tersebut dengan nilai MIC $0,25 \mu \mathrm{g} / \mathrm{ml}$. Sefiksim menunjukkan aktivitas yang sangat baik untuk galur yang resisten terhadap kloramfenikol, termasuk galur penghasil $\beta$-laktamase yang resisten terhadap amoksisilin. Hal ini menunjukkan stabilitas $\beta$-laktamasenya yang tinggi. Aktivitas antibakteri sefiksim ternyata sebanding dengan seftriakson, ofloksasin, dan siprofloksasin, yang saat ini sering digunakan untuk mengobati demam tifoid. Nilai MIC yang didapat dari Etest berkorelasi baik dengan hasil metoda dilusi agar konvensional. Hal ini menunjukkan bahwa Etest adalah suatu metoda baru yang mudah dilakukan dan berguna untuk penentuan MIC. Sebagai kesimpulan, sefiksim oral merupakan obat altematif yang aman dan efektif untuk penatalaksanaan demam tifoid, bahkan untuk kasus-kasus S. typhi yang resisten terhadap berbagai jenis obat.
\end{abstract}

\begin{abstract}
The in vitro antibacterial activity of various antibiotics including cefixime against 73 clinical isolates of Salmonella typhi from a yariety of sources was evaluated by conventional agar-dilution method and Etest. 18 strains of these 73 strains were chloranphenicol and cotrimoxazole (sulfamethoxazole-trimethoprim) resistant and 12 of these 18 strains were also resistant to amoxicillin due to $\beta$-lactamase production. Cefixime showed excellent activity against all 73 strains with the MIC90 value of $0.25 \mu \mathrm{g} / \mathrm{ml}$. Reflecting its high b-lactamase stability, Cefixime also had excellent activity against chloramphenicol-resistant strains including $\beta$-lactamase-producing amoxicillin-resistant strains. Antibacterial activity of cefixime was comparable to ceftriaxone, ofloxacin, and ciprofloxacin, which are currently often used for the treatment of typhoid fever. The MIC values obtained from the Etest correlated well with the results of conventional agar-dilution method, suggesting the usefulness of the Etest as a new easy MIC determination method. In conclusion, oral cefixime can provide a safe and effective alternative for management of typhoid fever even in cases of multidrug-resistant $\mathrm{S}$. typhi.
\end{abstract}

\section{INTRODUCTION}

Typhoid fever continues to be one of the major public health problems in developing countries. Chloramphenicol was used as the first choice drug for typhoid fever until recently. However, causative organism Salmonella typhi is developing resistance to conventional antibiotics chloramphenicol, cotrimoxazole and ampicillin in many countries. Consequently, treatment of typhoid fever with conventional agents can frequently cause clinical treatment failures or bacterial relapses. Frequencies of these strains called MDR (Multi Drug Resistance) are reported to be $78.4 \%$ (1990) in India ${ }^{1}, 75 \%$ (1995) in Egypt ${ }^{2}, 77 \%$ (1995) in Pakistan ${ }^{3}$ and 86\% (1995) in Vietnam 4 . Re-

Dept of Infections Diseases,

Medicinal Biology Research Laboratories,

Fujisawa Pharmaceutical Co., Ltd., Osaka, Japan. flecting this changing trends of antibiotic susceptibility of S. typhi, various new agents having strong in vitro activity have been tried clinically for the treatment of MDR S. typhi.

\section{MATERIALS AND METHODS}

\section{Bacterial Strains}

Clinically isolated Salmonella typhi strains were provided by Dr. S. Matsushita of the Tokyo Metropolitan Research Laboratory of Public Health (37 strains isolated in Philippines in 1992-1994), Dr. K. Itoh of the National Institute of Infectious Diseases Japan (15 strains isolated in Japan in 1995-1997), Dr. Niimi of the Osaka City General Hospital ( 9 strains isolated in Japan in 1994-1997). The other 12 strains were from our laboratory stock (4 of them from Pakistan in 1991). Strains isolated in Japan were mainly from overseas travelers. 


\section{Antibiotics}

Cefixime, cefdinir, ofloxacin, ciprofloxacin, and nitrocefin were synthesized in our laboratories. Amoxicillin, sulfamethoxázole and trimethoprim were laboratory standard. Ceftriaxone and chloramphenicol were commercially available. Sulfamethoxazole and trimethoprim were mixed in the ratio of 5:1 to use as cotrimoxazole.

\section{Susceptibility testing}

Antibacterial activity of test antibiotics was determined by agar dilution method using Mueller-Hinton agar (Difco). Inoculum size was approximately $10^{3}$ c.f.u./spot. Etest (AB BIODISK, Sweden) was alsio used for determination of susceptibility of $S$. typhi to cefixime.

\section{Detection of $\beta$-lactamase}

$\beta$-lactamase activity was revealed by spotting cells on filter paper containing $500 \mathrm{mg} / \mathrm{ml}$ of chromogenic cephalosporin nitrocefin in $50 \mathrm{mM}$ potassium phosphate buffer $\mathrm{pH}$ 7.0.

\section{Analytical isoelectric focusing}

Exponentially growing cells of test strains in Trypticase-soy broth (BBL) were harvested, washed once, and resuspended in $1 / 20$ volume of $50 \mathrm{mM}$ potassium phosphate buffer $\mathrm{pH}$ 7.0. Crude extracts prepared by ultrasonic disruption were applied on an Ampholine PAG plate (pH 3.5 - 10: LKB). Electrofocusing was carried out using LKB Multiphor apparatus. Several kinds of known $\beta$-lactamases were also focused on the same gel. The enzyme activities were visualized on the gel with overlaying filter paper containing 500 $\mathrm{mg} / \mathrm{ml}$ of nitrocefin.

\section{RESULTS}

\section{Susceptibility of $S$. typhi to various antibiotics}

The susceptibility of 73 clinically isolated S. typhi strains was evaluated with the conventional agar-dilution method for cefixime, cefdinir, ceftriaxone, amoxicillin, ofloxacin, ciprofloxacin, chloramphenicol and cotrimoxazole.(Table 1 and Figure 1) Among the 73 strains of S.typhi, 18 strains were resistant to chloramphenicol as well as to cotrimoxazole. 12 of the 18 strains were also resistant to amoxicillin, while the growth of the remaining 6 strains was inhibited by amoxicillin at less than $0.5 \mu \mathrm{g} / \mathrm{ml}$. The other new $\beta$-lactam and quinolone antibiotics showed good an-
A) Total 73 strains

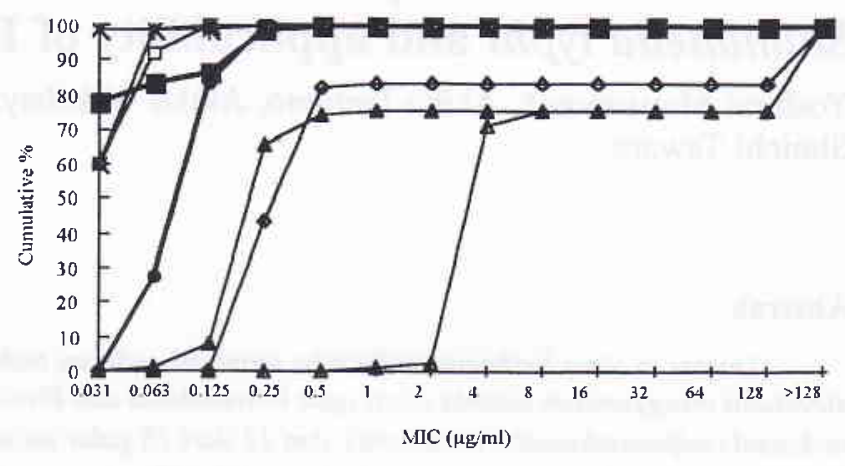

B) Chloramphenicol-sensitive 55 strains

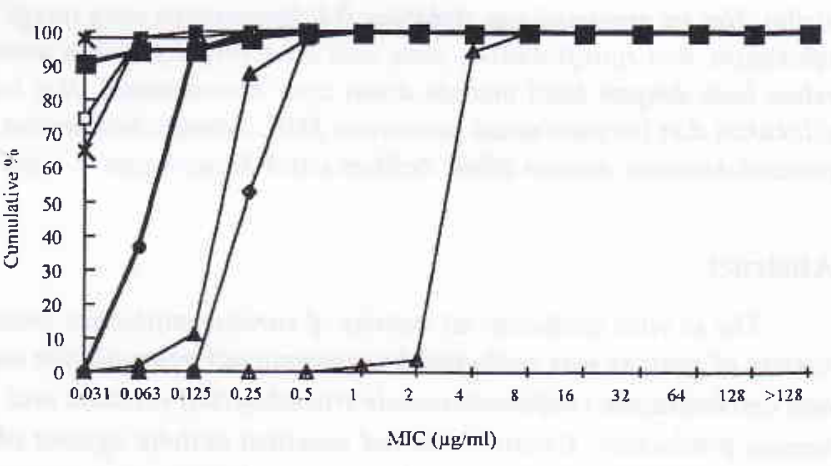

C) Chloramphenicol-resistant 18 strains

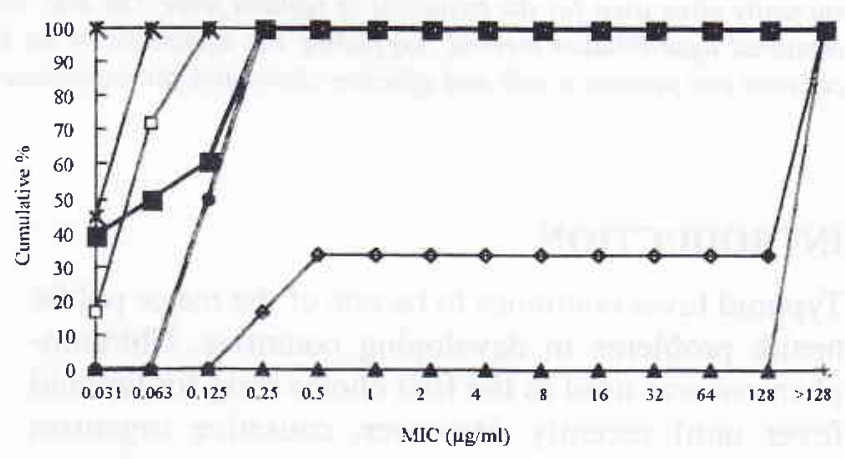

Figure 1. Cumulative distribution of MICs of antibiotics against Salmonella typhi.

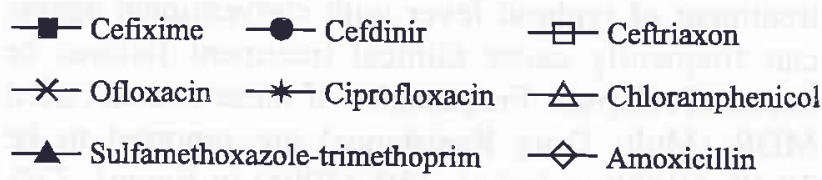

tibacterial activities, and all 73 strains were inhibited with less than $0.5 \mu \mathrm{g} / \mathrm{ml}$ concentration of each agent. The MICs of cefixime were distributed between 0.03 and $0.5 \mu \mathrm{g} / \mathrm{ml}$, and the $\mathrm{MIC}_{90}$ value was $0.25 \mu \mathrm{g} / \mathrm{ml}$. There were no cefixime resistant strains in this study. 
Table 1. Antibacterial activity of cefixime against Salmonella typhi

\begin{tabular}{|c|c|c|c|c|c|c|c|c|c|c|c|c|c|c|c|c|}
\hline \multirow{2}{*}{$\begin{array}{l}\text { Salmonella typhi } \\
\text { (No. of strains) }\end{array}$} & \multirow[t]{2}{*}{ Antibiotic } & \multicolumn{12}{|c|}{ MIC distribution $(\mu \mathrm{g} / \mathrm{ml})$} & \multirow[t]{2}{*}{ MIC range } & \multirow[t]{2}{*}{$\mathrm{MIC}_{50}$} & \multirow[t]{2}{*}{$\mathrm{MIC}_{90}$} \\
\hline & & $\square .031$ & 0.063 & 0.125 & 0.25 & 0.5 & 1 & 2 & 4 & 8 & 16 & 3264 & $128>128$ & & & \\
\hline \multirow[t]{8}{*}{ Total (73) } & Cefixime & 57 & 4 & 2 & 9 & 1 & & & & & & & & $\square .0 .031 \sim 0.5$ & {[] .0 .031} & 0.25 \\
\hline & Cefdinir & & 20 & 41 & 12 & & & & & & & & & $0.063 \sim 0.25$ & 0.125 & 0.25 \\
\hline & Ceftriaxone & 44 & 23 & 6 & & & & & & & & & & $0.0 .031 \sim 0.125$ & 0.0 .031 & 0.063 \\
\hline & Amoxicillin & & & & 32 & 28 & 1 & & & & & & 12 & $0.25 \sim 128$ & 0.5 & $>128$ \\
\hline & Ofloxacin & 44 & 28 & 1 & & & & & & & & & & $0.0 .031 \sim 0.125$ & ๑.0.031 & 0.063 \\
\hline & Ciprofloxacin & 72 & & & 1 & & & & & & & & & [. $0.031 \sim 0.25$ & 0.0 .031 & ‥0.031 \\
\hline & Chloramphenicol & & & & & & 1 & 1 & 50 & 3 & & & 18 & $1 \sim>128$ & 4 & $>128$ \\
\hline & Cotrimoxazole & & 1 & 5 & 42 & 6 & 1 & & & & & & 18 & $0.063 \sim 128$ & 0.25 & $>128$ \\
\hline \multirow{8}{*}{$\begin{array}{l}\text { Chloramphenicol } \\
\text { - sensitive (55) }\end{array}$} & Cefixime & 50 & 2 & & 2 & 1 & & & & & & & & {$[.0 .031 \sim 0.5$} & 0.0 .031 & 0.0 .031 \\
\hline & Cefdinir & & 20 & 32 & 3 & & & & & & & & & $0.063 \sim 0.25$ & 0.125 & 0.125 \\
\hline & Ceftriaxone & 41 & 13 & 1 & & & & & & & & & & ‥0.031 0.125 & - .0 .031 & 0.063 \\
\hline & Amoxicillin & & & & 29 & 25 & 1 & & & & & & & $0.25 \sim 1$ & 0.25 & 0.5 \\
\hline & Ofloxacin & 36 & 18 & 1 & & & & & & & & & & $0.0 .031 \sim 0.125$ & 0.0 .031 & 0.063 \\
\hline & Ciprofloxacin & 54 & & & 1 & & & & & & & & & ‥0.031 0.25 & [1.0.031 & $\square .0 .031$ \\
\hline & Chloramphenicol & & & & & & 1 & 1 & 50 & 3 & & & & $1 \sim 8$ & 4 & 4 \\
\hline & Cotrimoxazole & & 1 & 5 & 42 & 6 & 1 & & & & & & & $0.063 \sim 1$ & 0.25 & 0.5 \\
\hline \multirow{8}{*}{$\begin{array}{l}\text { Chloramphenicol } \\
\text { - resistant (18) }\end{array}$} & Cefixime & 7 & 2 & 2 & 7 & & & & & & & & & $0.0 .031 \sim 0.25$ & 0.063 & 0.25 \\
\hline & Cefdinir & & & 9 & 9 & & & & & & & & & $0.125 \sim 0.25$ & 0.125 & 0.25 \\
\hline & Ceftriaxone & 3 & 10 & 5 & & & & & & & & & & ‥0.031 0.125 & 0.063 & 0.125 \\
\hline & Amoxicillin & & & & 3 & 3 & & & & & & & 12 & $0.25 \sim 128$ & $>128$ & $>128$ \\
\hline & Ofloxacin & 8 & 10 & & & & & & & & & & & ‥0.031 0.063 & 0.063 & 0.063 \\
\hline & Ciprofloxacin & 18 & & & & & & & & & & & & ㄷ.0.031 & ‥0.031 & ๑.0.031 \\
\hline & Chloramphenicol & & & & & & & & & & & & 18 & $>128$ & $>128$ & $>128$ \\
\hline & Cotrimoxazole & & & & & & & & & & & & 18 & $>128$ & $>128$ & $>128$ \\
\hline
\end{tabular}

\section{Relation between $\beta$-lactamase production and susceptibility to cefixime}

Amoxicillin-resistant strains were all $\beta$-lactamasepositive by easy spotting test. However, susceptibilities of these 12 strains to cefixime, cefdinir and ceftriaxone were not different from other strains (Table 2). $\beta$-lactamases produced by these strains had $\mathrm{pI}$ 5.4 which was the same as TEM-1 type, the most common plasmid-mediated $\beta$-lactamase in gramnegative bacteria world-wide.

\section{Correlation between MICs from conventional agar-dilution method and Etest}

The MIC values of cefixime were also measured by the Etest system, a new convenient MIC evaluation method. The results obtained from the Etest were well correlated with the data from the conventional method, with the $\mathrm{R}^{2}$ value of 0.7964 (Figure 2). This result supports usefulness of the Etest in the MIC determination of $S$. typhi to cefixime.

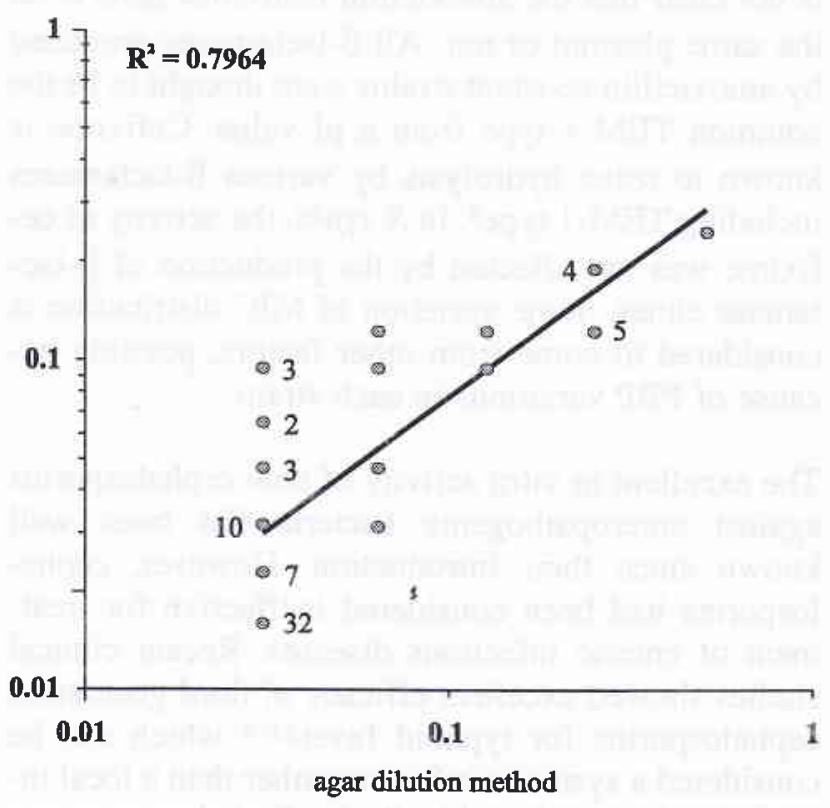

Figure 2. Correlation between MICs determined by Etest and agar dilution method. 
Table 2 List of $\beta$-lactamase producing Salmonella typhi strains

\begin{tabular}{|c|c|c|c|c|c|c|c|c|c|}
\hline \multirow{2}{*}{$\begin{array}{c}\text { Strain } \\
\text { No }\end{array}$} & \multirow{2}{*}{$\begin{array}{l}\text { Possible } \\
\text { origin }\end{array}$} & \multicolumn{8}{|c|}{$\mathrm{MIC}: \mu \mathrm{g} / \mathrm{ml}$} \\
\hline & & Cefixime & Cefdinir & Ceftriaxone & Amoxicillin & Ofloxacin & Ciprofloxacin & Chloramphenicol & Cotrimoxazole \\
\hline 11001 & Pakistan & $\cdot 0.031$ & 0.125 & 0.063 & $>128$ & $\cdot 0.031$ & $\cdot 0.031$ & $>128$ & $>128$ \\
\hline 11002 & Pakistan & $\cdot 0.031$ & 0.125 & 0.063 & $>128$ & $\cdot 0.031$ & $\cdot 0.031$ & $>128$ & $>128$ \\
\hline 11003 & Pakistan & $\bullet 0.031$ & 0.125 & 0.063 & $>128$ & $\cdot 0.031$ & $\cdot 0.031$ & $>128$ & $>128$ \\
\hline 11004 & Pakistan & $\cdot 0.031$ & 0.125 & 0.063 & $>128$ & $\cdot 0.031$ & $\cdot 0.031$ & $>128$ & $>128$ \\
\hline 13006 & Philippines & 0.125 & 0.125 & 0.063 & $>128$ & 0.063 & $\bullet 0.031$ & $>128$ & $>128$ \\
\hline 15005 & India & 0.25 & 0.25 & 0.125 & $>128$ & 0.063 & $\cdot 0.031$ & $>128$ & $>128$ \\
\hline 15006 & Japan & 0.25 & 0.25 & 0.125 & $>128$ & 0.063 & $\cdot 0.031$ & $>128$ & $>128$ \\
\hline 15007 & unclear & 0.25 & 0.25 & 0.063 & $>128$ & 0.063 & $\cdot 0.031$ & $>128$ & $>128$ \\
\hline 15008 & India & 0.25 & 0.25 & 0.125 & $>128$ & 0.063 & $\cdot 0.031$ & $>128$ & $>128$ \\
\hline 16004 & SEA & 0.25 & 0.25 & 0.125 & $>128$ & 0.063 & $\bullet 0.031$ & $>128$ & $>128$ \\
\hline 17008 & India & 0.25 & 0.25 & 0.063 & $>128$ & 0.063 & $\cdot 0.031$ & $>128$ & $>128$ \\
\hline 17009 & India & 0.25 & 0.25 & 0.125 & $>128$ & 0.063 & $\cdot 0.031$ & $>128$ & $>128$ \\
\hline
\end{tabular}

\section{DISCUSSION}

The problem of resistance is inevitable in chemotherapy of infectious diseases. Typhoid fever is not an exception. Transferable MDR plasmid coding for chloramphenicol, cotrimoxazole, and ampicillin has been spread over $S$. typh $i$ in many areas of the world ${ }^{1-4}$. Approximately one-fourth of strains (18/73) we used in this study were found to be resistant to these conventional agents. These resistance genes are probably coded on the same transferable plasmid, although it is not clear that the amoxicillin resistance gene is on the same plasmid or not. All $\beta$-lactamases produced by amoxicillin resistant strains were thought to be the common TEM-1 type from a pI value. Cefixime is known to resist hydrolysis by various $\beta$-lactamases including TEM-1 type 5 . In $S$. typhi, the activity of cefixime was not affected by the production of $\beta$-lactamase either. Some variation of MIC distribution is considered to come from other factors, possibly because of PBP variations in each strain.

The excellent in vitro activity of new cephalosporins against enteropathogenic bacteria has been well known since their introduction. However, cephalosporins had been considered ineffective for treatment of enteric infectious diseases. Recent clinical studies showed excellent efficacy of third generation cephalosporins for typhoid fever2,6-8 which can be considered a systemic infection rather than a local intestinal infection like Shigellosis. Cephalosporins can work against certain types of enteric infectious diseases such as typhoid fever. Conversely, cephalospor- ins are not effective in other enteric infectious diseases such as Shigellosis. The reason for this difference in activity is presumed to be due to the infection mechanisms peculiar to each bacterial species such as bacterial distribution in the body, toxin production and so on. Further microbiological and clinical investigations are required.

The new antibiotics, cefixime, cefdinir, ceftriaxone, ofloxacin, and ciprofloxacin, showed excellent antibacterial activities against the clinical isolates of S.typhi. This result supports the clinical usefulness of these new agents for the treatment of typhoid fever. They have already been proven to be clinically effective 2-4,6-12. However, new quinolone antibiotics should not be administered to pediatric patients due to possible adverse drug reactions. $\beta$-lactam antibiotics can be safely used for pediatric patients, although parenteral ones are more costly in terms of requiring hospitalization, and drug acquisition, as well as being less convenient than oral administration.

Cefixime, the first oral third generation cephalosporin, is currently commercially available in about sixty countries, and its clinical efficacy and safety in children have been well proven by numerous clinical trials and large-scale post marketing surveillance 13. Cefixime can also be administered in a once or twice daily dosing regimen, which can enhance patient compliance, especially in children who sometimes refuse oral administration. Several clinical trials have also shown its usefulness in the treatment of pediatric typhoid fever $2,6-8$. 
It is recommended that quinolones or 3 rd generation cephalosporins should be used to treat suspected typhoid fever in areas where MDR S. typhi is prevalent, until culture and sensitivity results are available. Cefixime provides a safe, effective and cheaper oral option for the treatment of typhoid fever in children, especially in endemic MDR areas.

\section{REFERENCES}

1. Sugandhi Rao, P Rajashekar, V Varghese, GK Shivananda, PG. Emergence of multidrug-resistant Salmonella typhi in rural southern India. Am J Trop Med Hyg 1993; 48(1): 108-11.

2. Girgis NI, Sultan Y, Hammad O, Farid Z. Comparison of the efficacy, safety and cost of cefixime, ceftriaxone, and aztreonam in the treatment of multidrug-resistant Salmonella typhi septicemia in children. Pediatr Infect Dis J 1995; 14(7): 6035.

3. Mirza SH, Beeching NJ, Hart CA. The prevalence and clinical features of multi-drug resistant Salmonella typhi infections in Bauchistan, Pakistan. Ann Trop Med Parasitol 1995; $89(5)$ : 515-9.

4. Vinh H, Wain J, Hanh VTN, Nga CN, Chinh MT, Bethell D, Hoa NTT, Diep TS, Dung NM, White NJ. Two or three days of ofloxacin treatment for uncomplicated Multidrug-resistant typhoid fever in children. Antimicrobial Agent and Chemotherapy 1996; 40: 958-61.

5. Shigi Y, Matsumoto $Y$, Kaizu M, Fujishita $Y$, Kojo H. Mechanism of action of the new orally active cephalosporin
FK027. The Journal of Antibiotics 1984; 37(7): 790-6.

6. Girgis NI, Kilpatrick ME, Farid Z, Sultan Y, Podgore JK. Cefixime in treatment of enteric fever in children. Drugs Expt] Clin Res 1993; 19(1): 47-9.

7. Bhutta ZA, Khan JA, Molla AM. Therapy of multidrug-resistant typhoid fever with oral cefixime ys intravenous ceftriaxone. Pediatr Infect Dis J 1994; 13(11): 990-4

8. Girgis NI, Tribble DR, Sultan Y, Farid Z. Short course chemotherapy with cefixime in children with multidrug-resistant Salmonella typhi. Septicaemia. Journal of Tropical Pediatrics 1995; 41: 364-5.

9. Alsoub H, Uwayadah AK, Mater I, Zebeib M, Elhag KM. A clinical comparison of typhoid fever caused by susceptible and multidrug-resistant strains of Salmonella typhi. Br J Clin Pract 1997; 51(1): 8-10.

10. Alam MN, Haq SA, Das KK, Baral PK, Mazid MN, Siddique RU. Efficacy of ciprofloxacin in enteric fever: comparison of treatment duration in sensitive and multidrug-resistant Salmonella. Am J Trop med Hyg 1995; 53(3): 306-11.

11. Wistrom J, Norrby SR. Fluoroquinolones and bacterial enteritis, when and for whom? J Antimicrob Chemother 1995; 36(1): 23-39.

12. Seceer G, Kanra G, Figen G, Akan S, Ceyhan M, Ecevit Z, Ofloxacin versus co-trimoxazole in the treatment of typhoid fever in children. Acta Paediatrica Japonica 1997; 39: 218 21.

13. Nishio, H. An International Review of the Safety Profile of Cefixime Curr Ther Res 1994; 55 SuppA: 63-7. 